\title{
Factors Affecting Online Payment Method Decision Behavior of Consumers in Vietnam*
}

\author{
Thi Phuong Linh NGUYEN ${ }^{1}$, Van Hau NGUYEN ${ }^{2}$
}

Received: June 28, 2020 Revised: August 23, 2020 Accepted: August 28, 2020

\begin{abstract}
E-commerce development led to the explosion of online payment. Consumers have many choices when deciding on the online payment method for each transaction. Using a combination of both qualitative and quantitative methods with the help of SPSS AMOS version 22.0, the article explores the factors that influence consumers' online payment method decision behavior in Vietnam. Research results show that awareness of usefulness, awareness of risk, awareness of trust, awareness ease of use, product uncertainly perception and perceived behavioral control have effects on the behavior of deciding on online payment methods. Awareness of risk has the strongest negative impact on online payment method decision behavior and awareness of usefulness has the strongest positive impact on online payment method decision behavior. Based on these important results, the article proposes a number of implications: (i) continuing to invest and upgrade modern technology to ensure customer information absolutely confidential; (ii) converting all ATM cards on the market to EMV chip standard card technology; (iii) improving service activities, quickly handle things to create confidence for customers; (iv) credit institutions operating in the field of online payment linked to e-commerce sites, supermarkets, convenience stores, restaurants must ask partners to increase transparency for the products.
\end{abstract}

Keywords: E-Commerce, Online Payment Method, Customers, Vietnam

JEL Classification Code: D11, J33, L81

\section{Introduction}

In 1990, the advent of e-commerce introduced a unique way of doing business commerce for the consumer and business world. Since then, e-commerce has grown and changed dramatically with creating extraordinary benefits for customers and businesses worldwide (Bezovski, 2016). The number of people shopping via the Internet is

\footnotetext{
*Acknowledgements:

This research is funded by National Economics University, Hanoi, Vietnam.

${ }^{1}$ First Author and Corresponding Author. Faculty of Business Management, National Economics University, Vietnam [Postal Address: 207 Giai Phong Street, Hai Ba Trung District, Hanoi City, 10000-14000, Vietnam] Email: linhnp@neu.edu.vn

${ }^{2}$ Faculty of Political Theory, National Economics University, Vietnam. Email: haunv@neu.edu.vn

(c) Copyright: The Author(s)

This is an Open Access article distributed under the terms of the Creative Commons Attribution Non-Commercial License (https://creativecommons.org/licenses/by-nc/4.0/) which permits unrestricted non-commercial use, distribution, and reproduction in any medium, provided the original work is properly cited.
}

increasing, leading to a significant increase in worldwide transaction volume (Pozzi, 2013). Significant innovations in payment technology and infrastructure (Kahn \& Roberds, 2009) and significant changes in consumer payment habits (Pimentel, 2013) require new ways of processing payments between companies and consumers in e-commerce (Stroborn, Heitmann, Leibold, \& Frank, 2004). Payments and purchases are separated by the nature of e-commerce (Deufel \& Kemper, 2018). Merchants and consumers, purchase intention and goods are physically separated. This makes it more difficult for consumers to self-regulate when the consumption of goods is separated from payments (Prelec \& Loewenstein, 1998).

The Internet is a popular, collaborative and self-sufficient setting, used by millions of people around the world (Tham, Dastane, Johari, \& Ismail, 2019). Applied later than other customers in the world, Vietnam has about half of the population accessing the Internet and up to $70 \%$ of them are using smartphones (Le, Ngo, Trinh, \& Nguyen, 2020). Vietnam's rapidly growing e-commerce market includes 35.4 million users and generated more than US \$ 2.7 billion in revenue in 2019. However, more than $90 \%$ of payment 
transactions in Vietnam are cash payments and consumers prefer cash on delivery over online payment $(\mathrm{Vu}$, Nguyen, \& Dang, 2019). Meanwhile, the online payment in the world in general and in Vietnam in particular reduces the amount of cash in circulation, reduces the cost of printing money, preserving and transporting money, reducing social labor costs, at the same time, improving the efficiency of payment in the economy, contributing to speeding up the circulation of capital of the society, promoting the development of production of goods and monetary circulation.

Therefore, it is necessary to study the factors affecting online payment method decision behavior of consumers in Vietnam in the current context. The study selected the context in Hanoi, the capital of Vietnam, where the urban population is densely populated to conduct interviews and surveys.

\section{Theoretical Foundation}

Awareness of Usefulness: Awareness of usefulness refers to the extent to which a person believes that using a particular system will enhance the work performance (Davis, 1989). Online payment is effective and helpful at work when the characteristics of the online payment system meet the requirements and provide important value to users (Schierz, Schilke, \& Wirtz, 2010). Referring to the TAM model (Davis, 1989), TAM2 model (Venkatesh \& Davis, 2000), awareness of usefulness is understood as the benefits that consumers receive when using online payment systems. Awareness of usefulness has a positive impact on the decision of the online payment method (Gu, Lee, \& Suh, 2009). Therefore, the following hypothesis is formulated:

H1: Awareness of usefulness has a positive impact on consumers' behavior of deciding on online payment methods in Vietnam.

Awareness of Risk: Bauer (1960) argued that awareness of risk is related to uncertainty and consequences to consumers' actions. A common barrier to accepting online payments is the lack of security on the Internet (Wang, Wang, Lin, \& Tang, 2003). The security of credit card information, hackers or unreliable suppliers is a major concern for consumers. Awareness of risk reduces consumer confidence in online purchases and payments, causes fear of disclosing personal information (Yoon, 2002), causes financial losses (Napitupulu \& Kartavianus, 2014). From there, the following hypothesis is formulated:

H2: Awareness of risk has a negative impact on consumers' behavior of deciding on online payment methods in Vietnam.
Awareness of Trust: According to Lu, Yang, Chau, \& Cao (2011), awareness of trust plays an important role in promoting the intention to use services. Awareness of trust has an indirect influence on the level of risk of financial transactions (Yang, Pang, Liu, Yen, \& Tarn, 2015) and the results of awareness of trust also reduce the risk perception, leading to a positive decision on online payment (Yousafzai, Pallister, \& Foxall, 2003). Therefore, it can be said that awareness of trust plays an active role in consumers' decision to use online payment. When consumers have awareness of trust, it will minimize barriers when deciding to use online payment. Therefore, the proposed hypothesis is:

H3: Awareness of trust has a positive impact on consumers'behavior of deciding on online payment methods in Vietnam.

Awareness Ease of Use: Awareness ease of use is the degree to which a person believes that using a particular system will not require much effort (Davis, 1989). Improved technology systems that are easier to use and less complex will be accepted and used more (Davis, Bagozzi, $\&$ Warshaw, 1989). Awareness ease of use was studied to positively influence various technology systems such as mobile services (Wang, Lin, \& Luarn, 2006), mobile data services (Faziharudean \& Li-Ly, 2011) and commercial services (Kalinic \& Marinkovic, 2016). Awareness ease of use is aware when users feel the payment system is easy to understand and easy to use. Especially in online payment, a system that is considered easy to use should have a simple interface, clear steps, appropriate content and layout, understandable functions and notifications. Awareness ease of use is considered to greatly influence the adoption and use of new consumer technologies. From there, the authors propose the following hypothesis:

H4: Awareness ease of use has a positive impact on consumers' online payment decision-making behavior in Vietnam.

Subjective Norms: Subjective norms is the perceived social pressure to perform or not to perform a behavior (Ajzen, 1991). Park (2000) emphasized the influence of important people such as friends, relatives and colleagues to consumers who have positive subjective norms towards a behavior will also tend to engage in a positive behavior (Taylor \& Todd, 1995; Han, Hsu, \& Sheu, 2010). Many studies have concluded that subjective norms is an important factor in predicting intention and behavior (Baker, Al-Gahtani, \& Hubona, 2007; Dean, Raats, \& Shepherd, 2012; Ha \& Janda, 2012; Kumar, 2012). When consumers are aware that people who are important to them make online payment, they tend to do so. The proposed research hypothesis is as follows: 
H5: Subjective norms has a positive impact on consumers' behavior of deciding on online payment methods in Vietnam.

Product Uncertainty Perception: Product uncertainty perception is due to doubts about the actual quality and future performance of the product (Dimoka, Pavlou, \& Davis, 2011). In the network market, the interaction between seller and consumer is mediated by technology. Consumers often worry about poor product quality, weakness in freight forwarding, channels, and lack of professionalism online payment (Giao, 2020). After the purchase commitment, it will be difficult for consumers to follow the seller 's intention to respect the contract between the two parties, such as after-sales service and personal information protection. As a result, buyers form an uncertain product awareness, possibly related to their online payment decisions (Pavlou \& Dimoka, 2008; Ghose, 2009; Mavlanova \& Benbunan-Fich, 2010). Therefore, product uncertainty perception is a factor affecting customers' decision to pay online. The proposed hypothesis is as follows:

H6: Product uncertainty perception has a negative impact on consumers' behavior of deciding on online payment methods in Vietnam.

Perceived Behavioral Control: Perceived behavioral control is defined as an individual's confidence in the ability to perform behaviors (Stroborn, Heitmann, Leibold, \& Frank, 2004). Perceived behavioral control shows the degree of behavioral control, not the result of behavior (Polančič, Heričko, \& Rozman, 2010). In the context of the growing online payment, perceived behavioral control describes consumer awareness of the availability of resources, knowledge and opportunities needed to make payments. Perceived behavioral control has a direct impact on the decision to use a payment method (Kim, Tao, Shin, \& Kim, 2010). According to TPB, perceived behavioral control can be directly used to predict the implementation of acts. Therefore, the authors propose the hypothesis:

H7: Perceived behavioral control has a positive impact on consumers' behavior of deciding on online payment methods in Vietnam.

\section{Research Methodology}

\subsection{Survey and Sample}

Qualitative research was conducted through in-depth interviews with 10 consumers in Hanoi. The content of the interview focused on: online shopping, factors affecting the behavior of deciding on online payment methods, the influence of awareness of usefulness, the influence of awareness of risk, the influence of awareness of trust, the influence of awareness ease of use, the influence of subject norms, the influence of product uncertainly perception, the influence of perceived behavioral control, the behavior of deciding on online payment methods. Interviews were conducted for approximately 1 hour at the location selected by the interviewee. The content of the interview was stored, summarized and analyzed to conclude on the factors in the research model.

Table 1: Characteristics of the sample

\begin{tabular}{|c|c|c|}
\hline Category & $\begin{array}{l}\text { Number of } \\
\text { respondents }\end{array}$ & $\begin{array}{c}\text { Percentages } \\
(\%)\end{array}$ \\
\hline Gender & 370 & 100 \\
\hline Male & 124 & 33.5 \\
\hline Female & 241 & 65.1 \\
\hline Do not want to specify & 5 & 1.4 \\
\hline Age & 370 & 100 \\
\hline Under 18 & 5 & 1.4 \\
\hline From 18 to 30 & 336 & 90.8 \\
\hline From 31 to 40 & 21 & 5.7 \\
\hline Over 40 & 8 & 2.1 \\
\hline $\begin{array}{l}\text { Education } \\
\text { qualification }\end{array}$ & 370 & 100 \\
\hline $\begin{array}{l}\text { Have not graduated } \\
\text { from high school }\end{array}$ & 6 & 1.6 \\
\hline $\begin{array}{l}\text { Draduated from high } \\
\text { school }\end{array}$ & 35 & 9.5 \\
\hline $\begin{array}{l}\text { Intermediate/College/ } \\
\text { University }\end{array}$ & 306 & 82.7 \\
\hline Master/Doctor & 23 & 6.2 \\
\hline $\begin{array}{l}\text { Average incomel } \\
\text { month }\end{array}$ & 370 & 100 \\
\hline Less than 5 million & 248 & 67 \\
\hline From 5 - 10 million & 57 & 15.4 \\
\hline From 10 - 20 million & 46 & 12.4 \\
\hline Over 20 million & 19 & 5.2 \\
\hline $\begin{array}{l}\text { Frequency of online } \\
\text { payment }\end{array}$ & 370 & 100 \\
\hline Never & 26 & 7 \\
\hline 1-2 times/month & 150 & 40.5 \\
\hline 3-4 times/month & 98 & 26.5 \\
\hline 5-6 times/month & 33 & 9.2 \\
\hline Over 6 times/month & 62 & 16.8 \\
\hline
\end{tabular}


Quantitative research was used to measure the influence of factors on the behavior of deciding on online payment methods. This method is implemented through a questionnaire survey with consumers in Hanoi. The questionnaire surveys were distributed to consumers in Hanoi area through two forms: utilizing Google Forms - a web-based dorm solution system, which allows researchers to design only surveys and questionnaires; distributing directly to the respondents at shopping locations, schools, parks ... from January to April 2020.

The statistics of 370 observations in the quantitative research show that the sample of the factors affecting the behavior of deciding on online payment methods in Hanoi area is mainly women (accounting for $65.1 \%$ ) nearly twice as many as men (accounting for $33.5 \%$ ); most of them are between the ages of 18 and 30 (accounting for 90.8\%); the observations focused on people educated Intermediate/ College/University (accounting for $82.7 \%$ ); the average income per month is mostly below 5 million, specifically 248 observations $(67 \%)$, followed by the level of 5 to 10 million (15.4\%); finally, the frequency of online payment of surveyed consumers is usually $1-2$ times/month (accounting for $40.5 \%$ ), about 3-4 times/month (accounting for 26.5\%) and a relatively small proportion. Number of respondents often pay online more than 5 times/month (accounting for $26 \%$ ), besides there are some consumers who have never paid online (accounting for $7 \%$ ).

\subsection{Analyses}

The authors performed an analysis to assess the contributions of factors (awareness of usefulness, awareness of risk, awareness of trust, awareness ease of use, subjective norms, product uncertainty perception, perceived behavioural control) to online payment method decision behavior. The analysis process includes three main steps. Firstly, Cronbach's alpha and explorative factor analysis (EFA) are implemented to assess the reliability of variables. Secondly, confirmatory factor analysis (CFA) to evaluate models and scales. Finally, regression analysis to test hypotheses and assess the level of influence. In addition, the statistical analysis has been carried out using SPSS 22.0 and AMOS 22.0.

\subsection{Measures}

All scales used in our study were adapted from the past researches and a new observation suggested by the authors after in-depth interviews. The scales were scored on a 5-point Liker-type format from strongly disagree to strongly agree.

Awareness of usefulness (Cronbach's alpha $=0.869$ ): The scale developed by Gu, Lee, and Suh (2009); Hoa, Hien, and Lien (2019); Teoh, Chong, Lin, and Chua (2013), which is comprised of 4 items, including 'I find using online payment very convenient in updating and collecting necessary information' (0.813), 'I save money compared to traditional payments' $(0.871)$, 'I save more time when paying online' (0.811), 'I find it easier to make my financial transactions using online payment' $(0.830)$.

Awareness of risk (Cronbach's alpha $=0.859$ ): The scale developed by Hausman and Siekpe (2009); Hoa, Hien, and Lien (2019); Napitupulu and Kartavianus (2014); Yoon (2002), which is comprised of 4 items, including 'I am afraid of having my personal information disclosed when making payments online' (0.803), 'Errors that occur in online payments can cause financial damage to me' $(0.792)$, 'The online payment process may be corrupted' $(0.828)$, 'I realize many risks when using online payment' $(0.855)$.

Awareness of trust (Cronbach's alpha $=0.829$ ): The scale developed by Teoh, Chong, Lin, and Chua (2013); Yousafzai, Pallister, and Foxall (2003), which is comprised of 3 items, including 'I rely on an online payment system to protect my privacy' (0.789), 'I trust the online payment system will not cheat and lose money in transactions' (0.729), 'I believe the risk of paying online is low' (0.768).

Awareness ease of use (Cronbach's alpha $=0.905$ ): The scale developed by Guriting and Ndubisi (2006); Hamidinava and Madhoushi (2010); Teoh, Chong, Lin, and Chua (2013), which is comprised of 3 items, including 'I believe the risk of paying online is low' (0.868), 'Learning how to use online payment is easy' $(0.841)$, 'Online payment procedure is simple and easy' $(0.880)$.

Subjective norms (Cronbach's alpha $=0.624$ ): The scale developed by Vu, Nguyen, and Dang (2019), which is comprised of 3 items, including 'My family and my relatives all use online payment' (0.595), 'My friends use online payment and recommend it to me' $(0.313)$, 'The trend of online payment is increasingly popular' $(0.627)$.

Product uncertainty perception (Cronbach's alpha $=0.773)$ : The scale developed by Pavlou and Dimoka (2008); Xu and Riedl (2011), which is comprised of 3 items, including 'Product prices will affect my online payment decision' (0.667), 'Depending on the type of product I will pay online' (0.646), 'Product description influenced my online payment decision' (0.729).

Perceived behavioural control (Cronbach's alpha $=$ 0.846): The scale developed by Hoa, Hien, and Lien (2019); Kim, Tao, Shin, and Kim (2010); Vu, Nguyen, \& Dang (2019) and an observation (PBC2) proposed by the authors. This scale includes 3 items, including 'I have the necessary resources for using online payment' (0.804), 'I have the necessary knowledge for using online payment' $(0.758)$, 'Using online payment is entirely within my control' $(0.796)$.

Online payment method decision behavior (Cronbach's alpha $=0.668)$ : The scale developed by Hoa, Hien, and Lien (2019); He and Mykytyn (2007) which is comprised of 3 items, including ' $I$ have the necessary resources for using 
online payment' $(0.277)$, 'I have the necessary knowledge for using online payment' (0.323), 'Using online payment is entirely within my control (0.668). In particular, the third observation is excluded because of the item-sum correlation less than 0.3 .

\section{Results}

\subsection{Exploratory Factor Analysis (EFA)}

After assessing the reliability of scales by Cronbach's alpha, total of 25 items are used in the exploratory factor analysis (EFA). The results of testing the reliability of scales by the exploratory factor analysis shows that $\mathrm{KMO}=0.801$, Sig. $($ Bartlett's Test $)=0.000<0.005$. The final results of the exploratory factor analysis are presented at Table 2 .

\subsection{Confirmatory Factor Analysis (CFA)}

From the EFA analysis results, we have 8 official factors used in the research model. CFA analysis results from the sample with GFI $=0.940 ;$ TLI $=0.984>0.9$; $\mathrm{CFI}=0.987>0.9 ; \mathrm{CMIN} / \mathrm{df}=1,219 \leq 2$ and $\mathrm{RMSEA}=0.024$ $\leq 0.08$. Therefore, the calculation results show that the model's indicators are satisfied, the model is accepted with the research data.

Table 2: The results of exploratory factor analysis (EFA)

\begin{tabular}{|c|c|c|c|c|c|c|c|c|}
\hline & & & & & ent & & & \\
\hline & 1 & 2 & 3 & 4 & 5 & 6 & 7 & 8 \\
\hline AU1 & 0.837 & & & & & & & \\
\hline AU3 & 0.829 & & & & & & & \\
\hline $\mathrm{AU} 4$ & 0.827 & & & & & & & \\
\hline $\mathrm{AU} 2$ & 0.747 & & & & & & & \\
\hline AR4 & & 0.838 & & & & & & \\
\hline AR 2 & & 0.818 & & & & & & \\
\hline AR 1 & & 0.767 & & & & & & \\
\hline AR 3 & & 0.713 & & & & & & \\
\hline AEU2 & & & 0.927 & & & & & \\
\hline AEU1 & & & 0.913 & & & & & \\
\hline AEU3 & & & 0.901 & & & & & \\
\hline PBC2 & & & & 0.890 & & & & \\
\hline PBC3 & & & & 0.866 & & & & \\
\hline PBC1 & & & & 0.861 & & & & \\
\hline AT2 & & & & & 0.880 & & & \\
\hline AT3 & & & & & 0.858 & & & \\
\hline AT1 & & & & & 0.846 & & & \\
\hline PUP2 & & & & & & 0.856 & & \\
\hline PUP1 & & & & & & 0.852 & & \\
\hline PUP3 & & & & & & 0.779 & & \\
\hline SN2 & & & & & & & 0.853 & \\
\hline SN1 & & & & & & & 0.712 & \\
\hline SN3 & & & & & & & 0.689 & \\
\hline OPD2 & & & & & & & & 0.866 \\
\hline OPD1 & & & & & & & & 0.866 \\
\hline & & & & tive $\%=$ & & & & \\
\hline & & & & alues $=$ & & & & \\
\hline
\end{tabular}


The results of testing scales by CFA analysis have shown that the factor weights of the indicators for the concepts described in the Table 3, all factors have high significance levels ( $\mathrm{p}<0.000)$; the values of standardized weights are $>0.5$ (except for SN3), so the scales achieve the convergence value (Hoang \& Chu, 2008). However, subjective norms has the composite reliability of 0.624 less than 0.7 and the total variance extracted is 0.414 less than 0.5 , indicating that the survey data only reflects $41.4 \%$ of the relationship between observed variables. This factor, in other words, the correlation level between the observed variables of this factor is not high. Therefore, in next step, subject norms will be excluded from the research model.

Table 3: Testing of scales by confirmatory factor analysis (CFA)

\begin{tabular}{|c|c|c|c|}
\hline Scales and observed variables & Standardized weights & Composite reliability & Total variance extracted \\
\hline Awareness of usefulness & & 0.869 & 0.631 \\
\hline AU1 & 0.847 & & \\
\hline AU3 & 0.860 & & \\
\hline AU4 & 0.787 & & \\
\hline AU2 & 0.67 & & \\
\hline Awareness of risk & & 0.859 & 0.609 \\
\hline AR2 & 0.851 & & \\
\hline AR4 & 0.651 & & \\
\hline AR1 & 0.828 & & \\
\hline AR3 & 0.777 & & \\
\hline Awareness ease of use & & 0.905 & 0.762 \\
\hline AEU2 & 0.907 & & \\
\hline AEU1 & 0.862 & & \\
\hline AEU3 & 0.849 & & \\
\hline Perceived behavioural control & & 0.846 & 0.650 \\
\hline PBC2 & 0.851 & & \\
\hline PBC3 & 0.782 & & \\
\hline PBC1 & 0.783 & & \\
\hline Awareness of trust & & 0.829 & 0.621 \\
\hline AT2 & 0.850 & & \\
\hline AT3 & 0.767 & & \\
\hline AT1 & 0.743 & & \\
\hline Product uncertainty perception & & 0.773 & 0.546 \\
\hline PUP2 & 0.796 & & \\
\hline PUP1 & 0.778 & & \\
\hline PUP3 & 0.633 & & \\
\hline Subject norms & & 0.624 & 0.414 \\
\hline SN2 & 0.853 & & \\
\hline SN1 & 0.525 & & \\
\hline SN3 & 0.490 & & \\
\hline $\begin{array}{l}\text { Online payment method decision } \\
\text { behavior }\end{array}$ & & 0.668 & 0.502 \\
\hline OPD1 & 0.720 & & \\
\hline OPD2 & 0.697 & & \\
\hline
\end{tabular}


Table 4: Model summary

\begin{tabular}{|c|c|c|c|c|c|}
\hline Model & $\mathbf{R}$ & R square & R squared corrected & Std. Error of the Estimate & Durbin-Watson \\
\hline 1 & $.695^{\mathrm{a}}$ & .483 & .475 & .64024 & 1.914 \\
\hline
\end{tabular}

Table 5: Standardized regression coefficient

\begin{tabular}{|c|l|c|c|c|}
\hline \multicolumn{2}{|c|}{ Model } & $\begin{array}{c}\text { Standardized } \\
\text { coefficient }\end{array}$ & \multirow{2}{*}{ t } & Sig. \\
\cline { 3 - 5 } \multicolumn{1}{|c|}{} & Beta & & \\
\hline \multirow{4}{*}{1} & (Constant) & & 6.063 & 0.000 \\
\cline { 2 - 5 } & AU & 0.308 & 6.658 & 0.000 \\
\cline { 2 - 5 } & AT & 0.095 & 2.501 & 0.013 \\
\cline { 2 - 5 } & AEU & 0.276 & 7.230 & 0.000 \\
\cline { 2 - 5 } & PBC & 0.185 & 4.875 & 0.000 \\
\cline { 2 - 5 } & AR & -0.372 & -8.117 & 0.000 \\
\cline { 2 - 5 } & PUP & -0.215 & -5.663 & 0.000 \\
\hline \multicolumn{2}{|l|}{ Dependent variable: OPD } & \\
\hline
\end{tabular}

\subsection{Linear Regression Analysis}

The linear regression analysis model is shown in detail in Table 4. Adjusted R Square - R corrected square of 0.475 means that the independent variables influence $47.5 \%$ of the variation of the dependent variable, the remaining $52.5 \%$ is due to the variables outside the model and random errors.

Linear regression analysis (Table 5) shows that:

- Awareness of risk (AR) with a beta of -0.372 has the strongest negative impact on online payment method decision behaviour (OPD); awareness of usefulness (AU) with a beta of 0.308 has the strongest positive impact on online payment method decision behaviour (OPD).

- Awareness of ease of use (AEU), product uncertainty perception (PUP), perceived behavioural control $(\mathrm{PBC})$ are the variables that moderate impact on online payment method decision behaviour (OPD).

- Awareness of trust (AT) with a beta of 0.095 has the weakest impact on online payment method decision behaviour (OPD).

Thus, hypotheses H1, H2, H3, H4, H6, H7 are accepted. The hypothesis H5 is rejected at the Confirmatory Factor Analysis (CFA).

\section{Discussion and Implications}

\subsection{Discussion}

Awareness of usefulness positively influence online payment method decision behavior. The benefits that online payment brings to consumers such as faster payment, improved work efficiency. This result has been confirmed in the research of Schierz, Schilke, and Wirtz (2010). Awareness of risk in online payment has a negative impact on consumers' decision to make online payments. When consumers are aware of risks to online payment systems such as faulty online payments that cause financial loss, disruption of payment processes, fear of disclosure of personal information or confidentiality. Regarding credit cards, the higher hackers decide to pay with this method. This result is completely consistent with the study of Wang, Wang, Lin, and Tang (2003) when studying the barrier to online payment is the lack of security on the Internet; Thakur and Sirvastava (2014) when studying on risk perception in accepting online payments via Internet and mobile; Napitupulu and Kartavianus (2014) when studying of errors in online payment causing financial losses.

Awareness of trust means that the belief that consumers will make online payments does not affect consumers' decision to make online payments. The influence of the perception of trust has not really had a strong impact on promoting the use of online payment by consumers. Although the results of this study do not coincide with the findings of Lu, Yang, Chau, and Cao (2011) when researched awareness of trust plays an important role in promoting the intention to use services in Hong Kong; the study of Yousafzai, Pallister, and Foxall (2003) confirmed that trust has an indirect effect on the level of risk associated with financial transactions. This can be explained by the difference in the context and the object of study.

Awareness ease of use also affects consumers' decision to make online payments. Awareness ease of use is perceived when consumers feel the payment system is easy to understand and implement. This will affect the acceptance and use of consumer technology. This assertion coincides with the results of Kalinic and Marinkovic (2016).

Subjective norms is one of the factors that positively influence consumers' decision to make online payments. The subjective norms is the influence of close people such as family, friends, colleagues, when those who positively impact consumers will contribute to the decision-making behavior of online payment. The results of this study are consistent with the research of Taylor and Todd (1995) and the study of Han, Hsu, and Sheu (2010).

Product uncertainly perception is a factor that has a negative impact on consumers' online payment behavior. Consumers cannot directly check products, asymmetric 
information among consumers makes consumers unsure about the products to make payment decisions online. This research result is completely consistent with the research of Pavlou and Dimoka (2008), Mavlanova and Benbunan-Fich (2010).

Perceived behavioral control is the weakest positive influence on consumers' behavior of deciding on online payment methods. When consumers are aware of the ability and eligibility to make payments online, the intention will increase and vice versa. This result is consistent with the study of Stroborn, Heitmann, Leibold, and Frank (2004) and the study of Kim, Tao, Shin, and Kim (2010).

\subsection{Implications}

Vietnam is considered a potential market to develop online payment services for consumers. In the era of Industry 4.0 and towards 5.0 society - a super smart society, the problem of developing online payment methods is extremely urgent. Based on the research results, the authors offer some suggestions for companies to improve, promote and develop online payment methods of consumers in the future.

Firstly, continuing to invest and upgrade modern technology to ensure customer information absolutely confidential. Enterprises in Hanoi region in particular and Vietnam in general need to lower the fraud rate when paying online, increase the security solutions for electronic payment in the context of e-commerce development to believe that hackers do not take advantage of fraudulent practices.

Secondly, converting all ATM cards on the market to EMV chip standard card technology. EMV chip is an electronic chip with a processor like a computer with high technology, capable of storing and encrypting information with high security. In contrast to traditional EMV chip cards will generate a unique transaction code and never repeat. In case a consumer card is stolen information from a store, the fake card will never work because the stolen transaction code will not be reused, that card will be rejected. Currently, besides international banks such as ANZ, HSBC, CitiBank... Vietnamese banks are also on the way to fully convert to EMV cards. There are many big banks introducing international credit and debit cards with advanced EMV chips such as VIB, VietinBank, VietcomBank, Techcombank, ACB, Sacombank... In the future, all banks must switch to Chip card for the security and safety of customers.

Thirdly, when there are bad situations like losing money in customers, or making payment of errors that cause financial damage, banks and financial institutions need to improve service activities, quickly handle things to create confidence for customers from which peace of mind using online payment methods.

Finally, credit institutions operating in the field of online payment linked to e-commerce sites, supermarkets, convenience stores, restaurants must ask partners to increase transparency for their products to help consumers trust the products. In addition, not only e-commerce sites but other units that use online payment methods need to regulate product images, limit risks when buying online for product quality. When programming, we need to create a tool that allows brands to provide unlimited product images and videos on the application website. Thereby, consumers easily make decisions on the choice of online payment method.

\subsection{Limitations}

The study of factors affecting online payment method decision behavior of consumers still has some limitations: Firstly, the research scope of the research is consumers in Hanoi. However, the subjects mainly surveyed were between the ages of 18-30 and lacked other subjects in the age group. Therefore, the sample does not represent all consumers in Hanoi. Secondly, the authors conducted a survey of consumers in Hanoi with a convenient sampling method so it was difficult to achieve a high level of representation. Thirdly, consumers' online payment decision-making behavior is also influenced by many other factors besides the seven groups of factors mentioned.

\section{References}

Ajzen, I. (1991). The theory of planned behavior, Organizational Behavior and Human Decision Processes, 50(2), 179-211.

Baker, E. W., Al-Gahtani, S. S., \& Hubona, G. S. (2007). The effects of gender and age on new technology implementation in a developing country. Information Technology \& People, 20(4), 352-375. https://doi.org/10.1108/09593840710839798

Bauer, R. A. (1960). Consumer behavior as risk taking. In: R. S. Hancock (Ed.), Dynamic Marketing for a Changing World (pp. 389-398). The 43rd Conference of the American Marketing Association.

Bezovski, Z. (2016). The future of the mobile payment as electronic payment system. European Journal of Business and Management, 8(8), 127-132.

Davis, F. D. (1989). Perceived usefulness, perceived ease of use, and user acceptance of information technology. MIS Quarterly, 13(3), 319-340.

Davis, F. D., Bagozzi, R. P., \& Warshaw, P. R. (1989). User acceptance of computer technology: a comparison of two theoretical models. Management Science, 35(8), 982-1003. https://doi.org/10.1287/mnsc.35.8.982

Dean, M., Raats, M. M., \& Shepherd, R. (2012). The Role of Self-Identity, Past Behavior, and Their Interaction in Predicting Intention to Purchase Fresh and Processed Organic Food. Journal of Applied Social Psychology, 42(3), 669-688. https://doi.org/10.1111/j.1559-1816.2011.00796.x 
Deufel, P., \& Kemper, J. (2018). Online Payment Method Selection: The Habitual Choice of Deferring Payment. International Conference on Information Systems, San Francisco, CA.

Dimoka, A., Pavlou, P. A., \& Davis, F. D. (2011). Research commentary-NeuroIS: The potential of cognitive neuroscience for information systems research. Information Systems Research, 22(4), 687-702.

Faziharudean, T. M., \& Li-Ly, T. (2011). Consumers' behavioral intentions to use mobile data services in Malaysia. African Journal of Business Management, 5(5), 1811. https://doi. org/10.5897/AJBM10.794

Ghose, A. (2009). Internet exchanges for used goods: An empirical analysis of trade patterns and adverse selection. MIS Quarterly, $33(2), 263-291$.

Giao, H. N. K. (2020). Customer Satisfaction at Tiki. vn E-Commerce Platform. Journal of Asian Finance, Economics, and Business, 7(4), 173-183. https://doi.org/10.13106/ jafeb.2020.vol7.no4.173

Gu, J. C., Lee, S. C., \& Suh, Y. H. (2009). Determinants of behavioral intention to mobile banking. Expert Systems with Applications, 36(9), 11605-11616. https://doi.org/10.1016/j. eswa.2009.03.024

Guriting, P., \& Ndubisi, N. O. (2006). Borneo online banking: evaluating customer perceptions and behavioural intention. Management Research News, 29(1/2), 6-15. https:// doi.org/10.1108/01409170610645402

Ha, H. Y., \& Janda, S. (2012). Predicting consumer intentions to purchase energy-efficient products. Journal of Consumer Marketing, 29(7), 461-469. https://doi. org $/ 10.1108 / 07363761211274974$

Han, H., Hsu, L. T. J., \& Sheu, C. (2010). Application of the theory of planned behavior to green hotel choice: Testing the effect of environmental friendly activities. Tourism Management, 31(3), 325-334. https://doi.org/10.1016/j.tourman.2009.03.013

Hamidinava, F., \& Madhoushi, M. (2010). Evaluating the features of electronic payment systems in Iranian bank users' view. International Review of Business Research Papers, 6(6), 78-94.

Hausman, A. V., \& Siekpe, J. S. (2009). The effect of web interface features on consumer online purchase intentions. Journal of Business Research, 62(1), 5-13. https://doi.org/10.1016/j. jbusres.2008.01.018

He, F., \& Mykytyn, P. P. (2007). Decision factors for the adoption of an online payment system by customers. International Journal of E-Business Research, 3(4), 1-32.

Park, H. S. (2000). Relationships among attitudes and subjective norms: Testing the theory of reasoned action across cultures. Communication Studies, 51(2), 162-175. https://doi. org/10.1080/10510970009388516

Hoa, N. T., Hien, L. M., \& Lien, V. T. P. (2019). Studying the Factors Affecting Online Payment Decision: A Case of Vietnamese Customers. Journal of Management Information and Decision Sciences, 22(1), 43-54. Available at: https:/www.abacademies.
org/articles/Studying-the-factors-affecting-online-paymentdecision-a-case-of-Vietnamese-customers-1532-5806-22-1-124. pdf

Hoang, T., \& Chu, N. M. N. (2008). Analyze research data with SPSS. Hanoi, Vietnam: Hong Duc Publishing House.

Kahn, C. M., \& Roberds, W. (2009). Why pay? An introduction to payments economics. Journal of Financial Intermediation, 18(1), 1-23. https://doi.org/10.1016/j. jfi.2008.09.001

Kalinic, Z., \& Marinkovic, V.(2016). Determinants of users'intention to adopt m-commerce: an empirical analysis. Information Systems and e-Business Management, 14(2), 367-387.

Kim, C., Tao, W., Shin, N., \& Kim, K. S. (2010). An empirical study of customers' perceptions of security and trust in e-payment systems. Electronic Commerce Research and Applications, 9(1), 84-95. https://doi.org/10.1016/j.elerap.2009.04.014

Kumar, B. (2012). Theory of planned behaviour approach to understand the purchasing behaviour for environmentally sustainable products. IIMA Working Papers WP2012-1208. Ahmedabad, India: Indian Institute of Management Ahmedabad, Research and Publication Department.

Le, H. B. H., Ngo, C. T., Trinh, T. T. H., \& Nguyen, T. T. P. (2020). Factor Affecting Customers' Decision to Use Mobile Banking Service: A Case of Thanh Hoa Province, Vietnam. Journal of Asian Finance, Economics and Business, 7(2), 205-212. https:// doi.org/10.13106/jafeb.2020.vol7.no2.205

Lu, Y., Yang, S., Chau, P. Y., \& Cao, Y. (2011). Dynamics between the trust transfer process and intention to use mobile payment services: A cross-environment perspective. Information \& Management, 48(8), 393-403. https://doi.org/10.1016/j. im.2011.09.006

Mavlanova, T., \& Benbunan-Fich, R. (2010). Counterfeit products on the Internet: The role of seller-level and productlevel information. International Journal of Electronic Commerce, 15(2), 79-104. https://doi.org/10.2753/JEC10864415150203

Napitupulu, T. A., \& Kartavianus, O. (2014). A structural equations modeling of purchasing decision through e-commerce. Journal of Theoretical \& Applied Information Technology, 60(2), 358364. http://www.jatit.org/volumes/Vol60No2/20Vol60No2.pdf

Pavlou, P. A., \& Dimoka, A. (2008). Understanding and mitigating product uncertainty in online auction marketplaces. In: 2008 Industry Studies Conference Paper. Available at SSRN: http:// dx.doi.org/10.2139/ssrn.1135006

Polančič, G., Heričko, M., \& Rozman, I. (2010). An empirical examination of application frameworks success based on technology acceptance model. Journal of Systems and Software, 83(4), 574-584. https://doi.org/10.1016/j. jss.2009.10.036

Prelec, D., \& Loewenstein, G. (1998). The red and the black: Mental accounting of savings and debt. Marketing Science, 17(1), 4-28. https://doi.org/10.1287/mksc.17.1.4 
Pimentel, R. (2013). Innovation in retail payments: Challenges posed to regulators. Journal of Payments Strategy \& Systems, 7(1), 90-97.

Pozzi, A. (2013). E-commerce as a stockpiling technology: Implications for consumer savings. International Journal of Industrial Organization, 31(6), 677-689. https://doi. org/10.1016/j.ijindorg.2013.05.005

Schierz, P. G., Schilke, O., \& Wirtz, B. W. (2010). Understanding consumer acceptance of mobile payment services: An empirical analysis. Electronic Commerce Research and Applications, 9(3), 209-216. https://doi.org/10.1016/j.elerap.2009.07.005

Stroborn, K., Heitmann, A., Leibold, K., \& Frank, G. (2004). Internet payments in Germany: a classificatory framework and empirical evidence. Journal of Business Research, 57(12), 1431-1437. https://doi.org/10.1016/S0148-2963(02)00433-2

Taylor, S., \& Todd, P. A. (1995). Understanding information technology usage: A test of competing models. Information Systems Research, 6(2), 144-176. https://doi.org/10.1287/ isre.6.2.144

Teoh, W. M. Y., Chong, S. C., Lin, B., \& Chua, J. W. (2013). Factors affecting consumers' perception of electronic payment: an empirical analysis. Internet Research, 23(4), 465-485. https:// doi.org/10.1108/IntR-09-2012-0199

Thakur, R., \& Srivastava, M. (2014). Adoption readiness, personal innovativeness, perceived risk and usage intention across customer groups for mobile payment services in India. Internet Research. Internet Research: Electronic Networking Applications and Policy, 24(3), 369-392. https:// doi.org/10.1108/IntR-12-2012-0244

Venkatesh, V., \& Davis, F. D. (2000). A theoretical extension of the technology acceptance model: Four longitudinal field studies. Management Science, 46(2), 186-204. https://doi. org/10.1287/mnsc.46.2.186.11926
Vu, V. V., Nguyen, Q. H., \& Dang, H. H. (2019). Factors affecting consumers' intention to use mobile payment, Journal of Financial, 2(1), 23-28.

Tham, K. W., Dastane, O., Johari, Z., \& Ismail, N. B. (2019). Perceived risk factors affecting consumers' online shopping behaviour. Journal of Asian Finance, Economics and Business, 6(4), 246-260. https://doi.org/10.13106/jafeb.2019. vol6.no4.249

Wang, Y. S., Lin, H. H., \& Luarn, P. (2006). Predicting consumer intention to use mobile service. Information Systems Journal, 16(2), 157-179. https://doi.org/10.1111/j.13652575.2006.00213.x

Wang, Y. S., Wang, Y. M., Lin, H. H., \& Tang, T. I. (2003). Determinants ofuseracceptance of Internetbanking: an empirical study. International journal of service industry management, 14(5), 501-509. https://doi.org/10.1108/09564230310500192

$\mathrm{Xu}$, Q., \& Riedl, R. (2011). Understanding online payment method choice: An eye-tracking study. In: D. Galletta \& T.-P. Liang (Eds.), Proceedings of the International Conference on Information Systems, ICIS 2011. December 4-7, Shanghai, China.

Yang, Q., Pang, C., Liu, L., Yen, D. C., \& Tarn, J. M. (2015). Exploring consumer perceived risk and trust for online payments: An empirical study in China's younger generation. Computers in Human Behavior, 50, 9-24. https:// doi.org/10.1016/j.chb.2015.03.058

Yoon, S. J. (2002). The antecedents and consequences of trust in online-purchase decisions. Journal of Interactive Marketing, 16(2), 47-63. https://doi.org/10.1002/dir.10008

Yousafzai, S. Y., Pallister, J. G., \& Foxall, G. R. (2003). A proposed model of e-trust for electronic banking. Technovation, 23(11), 847-860. https://doi.org/10.1016/S0166-4972(03)00130-5 